\title{
Study of Microbial Count in Soil under Different Land Use Systems in a Mollisol
}

\author{
Varsha Pandey*, Poonam Gautam and A.P. Singh
}

Department of Soil Science, College of Agriculture, G B Pant University of Agriculture and Technology, Pantnagar 263145, Uttarakhand, India

*Corresponding author

A B S T R A C T

\begin{tabular}{|l|}
\hline Ke y w o r d s \\
Microbial, Count, \\
Land use systems, \\
Mollisol
\end{tabular}

\section{Introduction}

Soil, a part of land, is the most important production factor for crops and at the same time influenced most by the farm practices. There is a considerable decline in soil fertility because of continuous growing of crops one after another without giving much consideration to the nutrient requirement of the crops grown (Ghosh et al., 2003). Microorganisms in the soil strongly influence soil processes (Garbeva et al., 2004), fulfill key roles in the decomposition of organic matter, the cycling of carbon and nitrogen and the formation and stabilization of soil structure (Loranger-Merciris et al., 2006). The constituents of soil microorganisms, such as microbial community diversity, have often been identified as sensitive indicators of biological indices for maintaining soil health and quality (Bending et al., 2004).

The soil microbial diversity is the most important functional component of the soil biota (Tate, 2000). Microbial adaptation to environmental conditions allows microbial analysis to be discriminating in soil health assessment, and changes in microbial populations and activities may therefore function as an excellent indicator of change in soil health (Kennedy et al., 1995; Pankhurst et al., 1995). 
Therefore, the present study was undertaken with the objective of assessment of soil microbial count under different land use systems.

\section{Materials and Methods}

Present study was undertaken at Norman E. Borlaug Crop Research Centre at Pantnagar in Mollisol soil. Five composite soil samples (0$20 \mathrm{~cm}$ depth) representing the whole area were collected randomly from different land use systems comprising of field crops, horticultural crops, agroforestry crops and fallow (uncultivated land) of the same block during kharif, 2017-18. Each composite soil sample was air dried, processed with the help of pestle and mortar, passed through $2 \mathrm{~mm}$ sieve and used for the analysis of biological properties.

The count of microorganisms (bacteria, fungi and actinomycetes) was carried out by using serial dilution pour plate method (Wollum, 1982).

The data were analysed statistically by using complete randomized design (C.R.D). The data collected on different soil properties were analysed applying ANOVA technique (Pansa and Sukhatme, 1985). The overall difference was tested by $\mathrm{F}$ test of significance at $5 \%$ level of probability. In case of significant $F$ test, C.D. at $5 \%$ was calculated for comparing treatment means.

\section{Results and Discussion}

\section{Bacterial population}

Bacterial population in soil significantly differed under different land use systems and ranged between 1.62 to $4.75 \times 10^{8} \mathrm{cfu} \mathrm{g}^{-1}$ soil (Table 1). Highest bacterial population was seen under eucalyptus + turmeric system which was significantly higher than population under all other land use systems. Bacterial population noted under poplar + turmeric system was significantly higher than that under rice-potato -okra, rice-wheat-green gram, rice-berseem + oat + mustard(fodder)maize + cowpea(fodder), sorghum(fodder)yellow sarson-black gram, ricepea(vegetable)-maize, maize-wheat-cowpea, guava + lemon and fallow(uncultivated) land use system. Bacterial population noted under maize-wheat-cowpea system was significantly higher than that under guava + lemon and fallow (uncultivated) land use system (Table 1).

Several researchers have reported that microbial diversity in soil is greater under agroforestry systems due to the effect of trees and organic matter inputs and also difference in litter quality, quantity and root exudates. The availability of carbonaceous materials and substrates such as amino acids, sugars and organic acids are important for supplying energy for the microbial population (Ferreira et al., 2012).

\section{Fungal population}

Fungal population in soil significantly varied under different land use systems and ranged between 1.35 to $4.15 \times 10^{5} \mathrm{cfug}^{-1}$ soil (Table 1). Highest fungal population was recorded under poplar + turmeric and eucalyptus + turmeric land use system. Fungal population noted under rice-potato-okra system was significantly higher than that under ricewheat-green gram, rice-berseem + oat + mustard(fodder)-maize + cowpea (fodder), sorghum(fodder)-yellow sarson-black gram, maize-wheat-cowpea, rice-pea (vegetable)maize, guava + lemon and fallow (uncultivated) land use system (Table 1). Fungal count recorded under rice-pea (vegetable)-maize and guava + lemon system were significantly higher than that under fallow (uncultivated) land use system. 
Bharadwaj and Omanwar (1992) observed that increase in the content of macronutrients in the soil caused increase in the fungal population. This might be the reason for higher fungal population under eucalyptus + turmeric and poplar + turmeric based land use system.

\section{Actinomycetes population}

Actinomycetes population in soil varied significantly under different land use systems and ranged between 1.87 to $4.51 \times 10^{6} \mathrm{cfu} \mathrm{g}^{-1}$ soil (Table 1). Highest actinomycetes population in soil was noted under eucalyptus + turmeric system which was significantly higher than population noted under poplar + turmeric, rice-wheat-green gram, riceberseem + oat + mustard (fodder)-maize + cowpea(fodder), sorghum (fodder)-yellow sarson-black gram, rice-pea (vegetable)maize, guava + lemon, maize-wheat-cowpea and fallow (uncultivated) land use system. Actinomycetes population noted under guava + lemon system was significantly higher than that under fallow (uncultivated) land use system (Table 1). Higher actinomycetes population under eucalyptus + turmeric land use system might be due to higher organic matter content of the soil and due to organic matter added to the soil through leaf litter which serves as a source of energy for microbial population. Similar results were also reported by Joshi and Yadav (2005).

\section{Total microbial population}

Total microbial population in soil significantly differed under different land use systems and ranged between 1.64 to $4.80 \times 10^{8} \mathrm{cfu} \mathrm{g}^{-1}$ soil. The highest microbial population was noted under eucalyptus + turmeric system which was significantly higher than total microbial population noted under all other land use systems. Total microbial population noted under guava + lemon was significantly higher than that under fallow (uncultivated) land use system (Table 1).

Among different groups of microbial population, the population of bacteria was recorded maximum followed by actinomycetes followed by fungal population. Similar order was also observed by Radhakrishnan et al., (2016) and Nayak (2017).

\section{Functional groups of microbes}

\section{Azotobacter}

Azotobacter population in soil significantly varied under different land use systems and ranged between 1.25 to $3.99 \times 10^{5} \mathrm{cfu} \mathrm{g}^{-1}$ soil. The highest population of Azotobacter was noted under eucalyptus + turmeric land use system which was significantly higher than that under rice-wheat-green gram, rice-potato okra, sorghum (fodder)-yellow sarson-black gram, rice-pea (vegetable)-maize, riceberseem + oat + mustard (fodder)-maize + cowpea (fodder), maize-wheat-cowpea, guava + lemon and fallow (uncultivated) land use system. Azotobacter population observed recorded under guava + lemon system was significantly higher than that under fallow (uncultivated) land use system (Table 2).

Higher population of Azotobacter was noted under eucalyptus + turmeric system followed by poplar + turmeric as compared to other systems. This might be due to the high soil organic carbon content under these systems. Azotobacter population ranged from $10 \times 10^{4}$ to $13 \times 10^{4} \mathrm{cfu} \mathrm{g}^{-1}$ soil in rhizospheric soil due to high organic matter content of the soil (Maurya et al., 2012).

\section{Phosphorous solubilizing bacteria (PSB)}

PSB population in soil significantly differed under different land use systems and ranged 
between 1.63 to $4.13 \times 10^{3} \mathrm{cfu} \mathrm{g}^{-1}$ soil. Highest population of PSB was recorded under eucalyptus + turmeric system which was significantly higher than that under all other land use systems.

PSB population noted under poplar + turmeric and rice-potato-okra system was significantly higher than that under rice-berseem + oat + mustard(fodder)-maize + cowpea(fodder), rice-wheat-green gram, sorghum(fodder)yellow sarson-black gram, rice-pea (vegetable)-maize, maize-wheat-cowpea, guava + lemon and fallow(uncultivated) land use system. PSB population observed under maize-wheat-cowpea system was significantly higher than that under fallow (uncultivated) land use system (Table 2).

Table.1 Bacterial, fungal and actinomycetes population in soil under different land use systems at $0-20 \mathrm{~cm}$ depth

\begin{tabular}{|c|c|c|c|c|}
\hline Land use systems & $\begin{array}{c}\text { Bacteria } \\
\left(\times 10^{8} \mathrm{cfu}^{-1}\right. \\
\text { soil })\end{array}$ & $\begin{array}{c}\text { Fungus } \\
\left(\times 10^{5} \mathrm{cfu} \mathrm{g}^{-1}\right. \\
\text { soil })\end{array}$ & $\begin{array}{l}\text { Actinomycetes } \\
\left(\times 10^{6} \mathrm{cfu}^{-1} \text { soil }\right)\end{array}$ & $\begin{array}{c}\text { Total count } \\
\left(\times 10^{8} \mathrm{cfu}^{-1}\right. \\
\text { soil })\end{array}$ \\
\hline Rice - wheat - green gram & 3.46 & 3.54 & 3.18 & 3.49 \\
\hline Rice - pea (vegetable) -maize & 3.16 & 2.47 & 2.94 & 3.19 \\
\hline Rice - potato - okra & 4.10 & 3.95 & 4.41 & 4.15 \\
\hline $\begin{array}{l}\text { Rice }- \text { berseem + oat }+ \text { mustard } \\
\text { (fodder) -maize+cowpea (fodder) }\end{array}$ & 3.42 & 2.91 & 3.06 & 3.46 \\
\hline Maize - wheat - cowpea & 2.94 & 2.69 & 2.33 & 2.97 \\
\hline $\begin{array}{l}\text { Sorghum (fodder) - yellow sarson } \\
\text { - black gram }\end{array}$ & 3.30 & 2.72 & 3.02 & 3.34 \\
\hline Guava + lemon & 2.72 & 2.46 & 2.47 & 2.74 \\
\hline Poplar + turmeric & 4.46 & 4.15 & 3.27 & 4.50 \\
\hline Eucalyptus + turmeric & 4.75 & 4.15 & 4.51 & 4.80 \\
\hline Fallow (uncultivated land) & 1.62 & 1.35 & 1.87 & 1.64 \\
\hline SEm \pm & 0.06 & 0.06 & 0.05 & 0.06 \\
\hline CD at $5 \%$ & 0.16 & 0.17 & 0.15 & 0.16 \\
\hline
\end{tabular}

Table.2 Azotobacter and phosphate solubilising bacterial count in soil under different land use systems at $0-20 \mathrm{~cm}$ depth

\begin{tabular}{|c|c|c|}
\hline Land use systems & $\begin{array}{c}\text { Azotobacter } \\
\left(\times 10^{5} \mathrm{cfug}^{-1} \text { soil }\right)\end{array}$ & $\begin{array}{l}\text { Phosphate solubilising } \\
\text { bacteria }\left(\times 10^{3} \mathrm{cfu}^{-1} \text { soil }\right)\end{array}$ \\
\hline Rice - wheat - green gram & 3.80 & 3.07 \\
\hline Rice - pea (vegetable) -maize & 3.01 & 2.69 \\
\hline Rice - potato - okra & 3.69 & 3.75 \\
\hline $\begin{array}{l}\text { Rice }- \text { berseem + oat }+ \text { mustard (fodder) - } \\
\text { maize+cowpea(fodder) }\end{array}$ & 2.90 & 3.25 \\
\hline Maize - wheat - cowpea & 2.65 & 2.38 \\
\hline Sorghum (fodder) - yellow sarson - black gram & 3.16 & 3.04 \\
\hline Guava + lemon & 2.49 & 2.38 \\
\hline Poplar + turmeric & 3.94 & 3.81 \\
\hline Eucalyptus + turmeric & 3.99 & 4.13 \\
\hline Fallow (uncultivated land) & 1.25 & 1.63 \\
\hline SEm \pm & 0.06 & 0.03 \\
\hline CD at $5 \%$ & 0.16 & 0.10 \\
\hline
\end{tabular}


PSB population of the soil was reported higher under systems with more organic carbon and nitrogen content which might be possible because organic carbon in soil supports the growth of phosphate solubilizing microbes. Similar results were observed by Vikram et al., (2007) and Venkateswarlu et al., (1984).

In conclusion, it is evident from the study that different land use systems have significant impact on soil biological health. Soils under agroforestry based systems showed best results with respect to soil biological environment followed by field crops, horticultural crop and the uncultivated land. The study indicates that dense cover and high litter fall in agroforestry systems led to higher organic matter content in soil which further favoured the microbial growth. Study may be helpful in evaluation of soil health and thereby enhancing cropping system sustainability.

\section{References}

Bending, G.D., Turner, M.K., Rayns, F., Marx, M.C., and Wood, M., 2004. Microbial and biochemical soil quality indicators and their potential for differentiating areas under contrasting agricultural management regimes. Soil Biology and Biochemistry. 36:17851792.

Bharadwaj Venkatesh and Omanwar, P.K., 1992. Impact of long-term fertility treatments on bulk density, water contents and microbial population of soil. Journal of the Indian Society of Soil Science, 40: 553-555.

Ferreira Araujo, A.S., Cavalho Leite, L.F., de Freitas Iwata, B., de Andrade Lira Jr., M., 2012. Microbiological processing in agroforestry systems. A review. Agron. Sustain. Dev., 33, 215-226.

Garbeva, P., Van Veen, J.A. and Van Elsas,
J.D. 2004. Microbial Diversity In: Soil selection of microbial populations by plant and soil type and implications for disease suppressiveness. Annual Review of Phytopathology. 42:243-270.

Ghosh, P.K., Dayal, D., Mandal, K.G., Wanjari, R.H., Hati, K.M., 2003. Optimization of fertilizer schedules in fallow and groundnut- based cropping systems and an assessment of system sustainability. Field Crops Res. 80, 8398.

Joshi P K and Yadav R K., 2005. Effect of sewage on microbiological and chemical properties and crop growth in reclaimed alkali soil. Proceeding of the International Conference on Soil, Water and Environment Quality, Issues and Strategies, January 28 February 1, 2005, New Delhi.

Kennedy, A. C. and Papendick, R. I. 1995. Microbial characteristics of soil quality. Journal of soil and water conservation May-June:243-248.

Loranger-Merciris, G., Barthes, L., Gastine, A. and Leadley, P. 2006. Rapid effects of plant species diversity and identity on soil microbial communities in experimental grassland ecosystems. Soil Biology and Biochemistry. 38:23362343.

Maurya, B.R., Kumar, A. and Singh, V. 2012. Diversity of Azotobacter and Azospirillum in Rhizosphere of different crop rotations in eastern Uttar Pradesh of India. Res. J. Microbio., 10: 625-630.

Nayak, D.R., Y.J. Babu., and T.K. Adhya, 2007. Long-term application of compost influences microbial biomass and enzyme activities in a tropical Aeric Endoaquept planted to rice under flooded condition. Soil Biology and Biochemistry, 39: 1897-1906.

Pankhurst, C. E., Hawke, B. G., McDonald, H. J., Kirkby, C. A., Buckerfield, J. C., Michelsen, P., O'Brien, K. A., Gupta, V. 
V. S. R., and Doube, B. M. (1995). Evaluation of soil biological properties as potential bioindicators of soil health. Australian Journal of Experimental Agriculture 35:1015-1028.

Panse, V.G. and Sukhatme, P.V. (1985) Statistical Methods for Agricultural Workers. Indian Council of Agricultural Research Publication, 87-89.

Radhakrishnan, S. and Varadharajan, M. (2016). Status of microbial diversity in agroforestry systems in Tamil Nadu, India. Journal of Basic Microbiology $56,662-669$.

Tate, R.L. (2000) Effects of heavy metal contamination and remediation on soil microbial communities in the vicinity of a zinc smelter. Journal of Environmental Quality. 27:609-617.

Venkateswarlu, B., A.V. Rao and P. Raina,
1984. Evaluation of phosphorus solubilization by microorganisms isolated from aridisols. Journal of Indian Soil science 32: 273-277.

Vikram, A., Alagawadi, Hamzehzarghani, H. and Krishnaraj, P.U. 2007. Factors Related to the Occurrence of Phosphate Solubilizing Bacteria and Their Isolation in Vertisols. International Journal of Agricultural Research 2 (7): 571-580.

Wollum, A.G. 1982. Cultural methods for soil microorganism. In: Methods of Soil Analysis, Part 2. Chemical and Microbiological Properties (Page, A. K., Millar, R. H. and Keeney, D. R. eds.) Agronomy Monograph No 9, ASA-SSSA Publisher, Madison, Wisconsin, USA. pp. 781-814.

\section{How to cite this article:}

Varsha Pandey, Poonam Gautam and Singh, A.P. 2019. Study of Microbial Count in Soil under Different Land Use Systems in a Mollisol. Int.J.Curr.Microbiol.App.Sci. 8(01): 16-21. doi: https://doi.org/10.20546/ijcmas.2019.801.002 